\title{
Urea nitrogen salvage mechanisms and their relevance to ruminants, non-ruminants and man
}

\author{
Gavin S. Stewart and Craig P. Smith* \\ School of Biological Sciences, Stopford Building, University of Manchester, Oxford Road, Manchester M13 9PT, UK
}

\begin{abstract}
Maintaining a correct balance of $\mathrm{N}$ is essential for life. In mammals, the major sources of $\mathrm{N}$ in the diet are amino acids and peptides derived from ingested proteins. The immediate endproduct of mammalian protein catabolism is ammonia, which is toxic to cells if allowed to accumulate. Therefore, amino acids are broken down in the liver as part of the ornithine-urea cycle, which results in the formation of urea - a highly soluble, biochemically benign molecule. Mammals cannot break down urea, which is traditionally viewed as a simple waste product passed out in the urine. However, urea from the bloodstream can pass into the gastrointestinal tract, where bacteria expressing urease cleave urea into ammonia and carbon dioxide. The bacteria utilise the ammonia as an $\mathrm{N}$ source, producing amino acids and peptides necessary for growth. Interestingly, these microbial products can be reabsorbed back into the host mammalian circulation and used for synthetic processes. This entire process is known as 'urea nitrogen salvaging' (UNS). In this review we present evidence supporting a role for this process in mammals - including ruminants, non-ruminants and man. We also explore the possible mechanisms involved in UNS, including the role of specialised urea transporters.
\end{abstract}

Urea: Ammonia: Gastrointestinal tract: Bacteria: Nitrogen balance: Growth

\section{Introduction}

$\mathrm{N}$ is essential for life. Unlike plants, animals are unable to fix $\mathrm{N}$ and must therefore obtain all their $\mathrm{N}$ requirements from the food they consume. The interplay of absorption of $\mathrm{N}$ and the excretion of $\mathrm{N}$ in the urine and faeces is the major factor in the homeostatic control of $N$ balance. Since survival depends on the availability of $\mathrm{N}$, mechanisms have evolved that maximise its utilisation and conservation.

The major sources of $\mathrm{N}$ in the diet are amino acids and peptides derived from ingested proteins. These are utilised as the building blocks of proteins and also can be used as an energy source. Proteins are constantly being synthesised and broken down as part of the normal biochemistry of life. The immediate endproduct of protein catabolism is ammonia, which is toxic to cells if allowed to accumulate. Evolution has dealt with this problem in several ways. In fish, ammonia passes out into the surrounding water and is detoxified simply by dilution. In terrestrial organisms this is not an option; therefore other processes have evolved. In mammals, amino acids are broken down as part of the ornithine-urea cycle. This process occurs in the liver and results in the formation of urea $\left(\mathrm{CO}\left(\mathrm{NH}_{2}\right)_{2}\right)$, a highly soluble, biochemically benign molecule. There is little doubt that the capacity to detoxify ammonia by synthesising urea was a major evolutionary advance away from an aquatic habitat, enabling exploitation of the terrestrial biosphere.

Another key event in the habitation of land was the capacity for animals to concentrate their urine. Importantly, urea was also a key player in the evolution of this faculty. To concentrate urine, and hence conserve water, a hyperosmotic compartment in the renal medulla consisting of $\mathrm{NaCl}$ and urea is formed in a process termed the urinary concentrating mechanism.

In recent years another role for urea has emerged that is beginning to re-ignite interest in the research community. Urea represents a no-through road to vertebrates because they do not constitutively express urease, an enzyme that cleaves urea into ammonia and carbon dioxide. However, bacteria that inhabit the gastrointestinal tract express urease and can utilise urea as an $\mathrm{N}$ source. Urea in the blood of the host is able to pass into the gastrointestinal tract, where it can be broken down. Interestingly, the story does not stop there. The $\mathrm{N}$ liberated in this process is available to the host and can re-enter the host circulation, to be used as a substrate for synthetic processes. Reclamation of urea-N from bacterially cleaved urea has become known as 'urea

\footnotetext{
Abbreviations: AQP, aquaporin; SIDS, sudden infant death syndrome; UNS, urea nitrogen salvaging.

* Corresponding author: Dr Craig Smith, fax +44 161275 5600, email craig.smith@ manchester.ac.uk
} 
nitrogen salvaging' (UNS; Fuller \& Reeds, 1998). UNS has previously been referred to as 'urea recycling'. However, the use of this term can be confusing, because it is urea-N not urea that is being recycled. In the past 'urea recycling' has also been used to refer to various processes including: the passage of urea into and out of the gut without further metabolism; the portion of total urea synthesised by the liver that enters the gut; urea-N that is returned, via ammonia, to the host. In the present review, we will use the term UNS to describe the process whereby $\mathrm{N}$ moieties derived from bacterial urea breakdown are utilised by the host.

The present review summarises the evidence supporting UNS in mammals, the potential mechanisms for UNS and its potential relevance to man.

\section{Urea nitrogen salvage}

The principle of UNS is shown in Fig. 1. In this process, urea passes from the circulation of the mammalian host into the digestive tract and is broken down by the resident bacteria into ammonia and carbon dioxide. The bacteria then use this ammonia to synthesise amino acids and nucleotides required for growth (Fuller \& Reeds, 1998). The host can absorb either the molecules synthesised by the bacteria or the ammonia itself, thus completing the 'salvaging' of urea-N (Fuller \& Reeds, 1998).

Since the diet, anatomy of the gastrointestinal tract, and degree of UNS are different between species, we have chosen to describe separately the data for different groups of mammals. The distinct groups discussed are (i) ruminants (for example, cattle, sheep), (ii) non-ruminants (for example, mice, rats, pigs) and, finally, (iii) man, who although non-ruminant, will be dealt with separately throughout the present review.

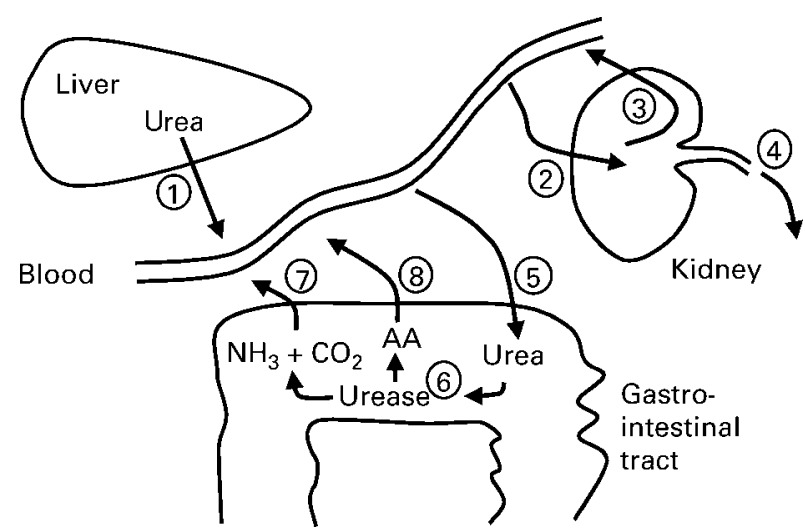

Fig. 1. Principle of urea nitrogen salvaging. Urea is produced in the liver, via the ornithine-urea cycle, and passed into the bloodstream (1). Urea is freely filtered in the kidney (2) and between 40 and $60 \%$ of the filtered urea is reabsorbed (3); the rest is excreted in the urine (4). Urea in the bloodstream can pass into the gastrointestinal tract, probably via specialised transporters (5), where it is broken down by the bacterial enzyme urease into ammonia and carbon dioxide (6). The ammonia can either be reabsorbed directly into the bloodstream (7), or utilised by the bacteria to produce amino acids and peptides, which in turn can be reabsorbed (8). The return of urea- $\mathrm{N}$ moieties to the host represents the 'salvaging' of the $\mathrm{N}$ present in urea.

\section{Ruminants}

For many years, UNS has been acknowledged to play a significant role in maintaining $\mathrm{N}$ balance in ruminant animals. This has resulted in a plethora of studies aimed at discerning factors that influence UNS as a means of improving livestock productivity. Accordingly, there is a wealth of data relevant to ruminant UNS. In the present review we give a basic overview of ruminant UNS and readers seeking a more in-depth treatise are directed to the excellent review by Lapierre \& Lobley (2001).

Inclusion within this group is reserved for animals that possess a specialised gastrointestinal organ known as the rumen. These animals, such as cattle (Archibeque et al. 2001), goats (Houpt \& Houpt, 1968) and sheep (Packett \& Groves, 1965), have a digestive system especially adapted to utilise the complex plant carbohydrates that they ingest. It is important at this stage to point out that the rumen is anterior to the small and large intestine, and that this is critical when considering the fate of the products of bacterial metabolism.

It has been estimated that between 40 and $80 \%$ of urea-N synthesised by the liver enters the ruminant gut (Harmeyer $\&$ Martens, 1980). A varying proportion of this is ultimately returned to the ruminant host for anabolism. In this respect, the rumen can be thought of as an on-board bioreactor into which urea passes and is hydrolysed by the large community of 'commensal' bacteria that reside there (Houpt \& Houpt, 1968).

Urea enters the ruminant gut by several routes. Although urea secreted in saliva accounts for between 10 and $40 \%$ of ruminal urea entry, the majority of urea enters across the gastrointestinal tract wall - particularly across the ruminal epithelium. There is also a minor inflow in the bile secretion and pancreatic juice (Varady et al. 1979). However, the relative contributions of these routes can vary enormously depending on a complex interaction of factors, including the composition of diet ingested. For example, in cattle fed a concentrate diet, saliva secretion accounted for $17 \%$ of the total gut entry of urea, whereas in cattle fed a forage diet this value increased to $36 \%$ (Lapierre \& Lobley, 2001). Recently, this fact has been utilised to modify diets and improve $\mathrm{N}$ retention for a given $\mathrm{N}$ intake. In one such study, simply changing the sorghum grain fed to cattle from 'dry-rolled' to 'steam-flaked' increased urea-N transfer across ruminal tissues from 32 to $42 \mathrm{~g} / \mathrm{d}$, hence increasing the supply of microbial protein for absorption and enabling a $15 \%$ improvement in whole-body $\mathrm{N}$ retention as a percentage of $\mathrm{N}$ intake (Theurer et al. 2002).

The transfer of urea directly into the rumen across the ruminal epithelium occurs by diffusion and nearly all the urea in the rumen is hydrolysed by bacterial urease to ammonia and carbon dioxide (Houpt \& Houpt, 1968). At normal blood urea levels, pre-treatment with anti-bacterial agents or thorough rinsing of the rumen (i.e. treatments that effectively remove the ruminal bacteria) lead to a significant reduction in urea movement into the rumen and hence ruminal urea hydrolysis. This suggests that bacterial urea metabolism may provide a concentration gradient down which urea diffuses into the rumen (Houpt \& Houpt, 1968).

Urea is transported across plasma membranes by specialised transporter proteins that are the products of 
two closely related genes, $S L C 14 a 1$, also known as the $U T-B$ gene, and $S L C 14 a 2$, also known as the $U T-A$ gene. It is therefore probable that the epithelia of the salivary glands and rumen possess these transporters. Several studies have demonstrated the presence of either mRNA transcripts encoding urea transporters or actual urea transporter proteins in rumen (Ritzhaupt et al. 1998; Marini \& van Amburgh, 2003; GS Stewart, C Graham, S Cattell, T Smith, NL Simmons and CP Smith unpublished results), but we are not aware of any study addressing the salivary gland. These proteins could potentially modulate urea flux into the rumen by either increased expression or activation. This and other aspects of urea transporters will be discussed in more detail below.

What is the fate of the urea produced by the liver that enters the gut? The current evidence indicates that ruminant animals utilise the released urea- $\mathrm{N}$ in a number of ways. In sheep, $30-50 \%$ of the urea that enters the digestive tract is returned to the host as ammonia, whereas this value is $25-40 \%$ for cattle (Lapierre \& Lobley, 2001). The ammonia produced by urea hydrolysis is directly reabsorbed passively, independent of ionic concentrations, from both the rumen and the post-ruminal gut, particularly the caecum and large intestine (Huntington, 1986). Koenig and coworkers reported that approximately $20 \%$ of ruminal ammonia flux in sheep is derived from urea-N rather than ingested N (Koenig et al. 2000). Released urea-N is also reabsorbed as microbial nucleic and amino acids, mainly in the small intestine (Huntington, 1986). In dairy cows, between 10 and $40 \%$ of bacterial $\mathrm{N}$ was derived from urea that had entered the digestive tract (Al-Dehneh et al. 1997), the precise contribution varying with diet. One model for $\mathrm{N}$ uptake from ovine gastrointestinal tract lumen predicted $11.8 \mathrm{~g}$ ammonia-N/d, $1.5 \mathrm{~g}$ nucleic acid-N/d and $8.7 \mathrm{~g}$ amino acid-N/d (Huntington, 1986). This indicates that approximately $50 \%$ of the bacterial $\mathrm{N}$ products absorbed by the host is ammonia, a value similar to contemporary values stated earlier. However, it is now more clearly understood that the precise fate of the released urea-N can vary enormously and is greatly affected by dietary factors. This fact is a very important consideration in modern feeding procedures for livestock.

In ruminants, UNS is recognised as being important for growth. From an agricultural point of view, this fact is exploited every year as large quantities of urea are used as a dietary supplement for ruminant animals worldwide. For example, replacing $30 \%$ of a low-quality forage diet with a controlled-release urea supplement improved $\mathrm{N}$ retention in sheep from $9 \mathrm{~g} / \mathrm{d}$ to $36 \mathrm{~g} / \mathrm{d}$ (Puga et al. 2001). However, there is of course a limit to the extent of urea supplementation that can be used. A recent study in cattle suggested that up to $40 \%$ of the degradable protein intake could be replaced by urea supplements without adverse affects (Koster et al. 2002). This practice of supplementing the diet with urea is the modern equivalent of farmers 'urinating on the fodder'. Because urine contains a high concentration of urea, this practice served to increase the $\mathrm{N}$ content of the diet fed to livestock (Bankir, 1996).

The exact contribution of UNS to overall $\mathrm{N}$ balance is thought to vary between species, depend on animal health, and be regulated by dietary $\mathrm{N}$ intake and $\mathrm{N}$ demand.
For example, it has been shown that net incorporation of urea into bacterial protein is inversely proportional to protein intake in Angus heifer calves (Bunting et al. 1989a). Just over half of the urea in the rumen of cattle calves maintained on a low-protein diet $(66.5 \mathrm{~g} \mathrm{~N} / \mathrm{d})$ was degraded, compared with $26 \%$ in calves on a high-protein $\operatorname{diet}(126 \mathrm{~g} \mathrm{~N} / \mathrm{d})$. However, it is not yet clear whether this change was due to less urea entering the gut, or whether it was simply due to the amount of urea-N being 'diluted' by the increased levels of ammonia derived from dietary $\mathrm{N}$, and/or the bacteria preferentially using amino acid-N. Interestingly, Bunting et al. (1989b) also reported that ruminal urease activity was higher in lowprotein-fed calves, and bacteria at or near the rumen wall preferentially utilised urea-derived ammonia.

Ruminants produce copious amounts of saliva - cattle can produce 220 to 250 litres saliva/d (Maekawa et al. 2002) - and delivery of urea into the rumen via saliva is thought to be of increased importance when animals are maintained on a low-protein diet (Hobson \& Wallace, 1982).

In sheep, studies investigating the amount of microbial protein entering the duodenum of animals fed a normal $(17.4 \mathrm{~g} \mathrm{~N} / \mathrm{d})$ or a low-protein $(7.5 \mathrm{~g} \mathrm{~N} / \mathrm{d})$ diet showed that microbial $\mathrm{N}$ production did not significantly differ between groups (Tebot et al. 2002). However, although the $\mathrm{N}$ intake was only $57 \%$ lower in low-protein diets, the excretion of urea in the urine was reduced by $84 \%$ (Tebot et al. 2002). This large decrease in urea excretion - brought about via reductions in renal plasma flow and glomerular filtration rate, and by increased urea reabsorption from tubules - is a wellknown effect of reduced protein intake in ruminants (Ergene \& Pickering, 1978; Leng et al. 1985). It can perhaps then be concluded that changes in renal function limited the drop in blood urea levels due to reduced urea synthesis and therefore helped maintain delivery of urea to the rumen (Tebot et al. 2002). In agreement with this, Marini \& van Amburgh (2003) reported in cattle that changing $\mathrm{N}$ intake in isoenergetic diets had no effect on the amount of $\mathrm{N}$ salvaged in the gut, but at low $\mathrm{N}$ intakes (i) more $\mathrm{N}$ was derived from blood urea, (ii) microbial yield was maintained, and (iii) renal urea clearance decreased, while gastrointestinal urea clearance increased. One interpretation of these studies would be that at low $\mathrm{N}$ intakes regulatory changes in renal and gastrointestinal function help 'maintain' UNS at normal levels, despite a reduction in urea synthesis. If correct, this suggests modulation of urinary and gastrointestinal urea handling occurs as part of an integrated response to conserve body $\mathrm{N}$.

Although studies agree on an important role for UNS in ruminant homeostasis, some studies disagree about the regulation of UNS. For example, Sarraseca et al. (1998) reported in sheep that the amount of urea that entered the digestive tract was always directly proportional to $\mathrm{N}$ intake, and that the proportion of gastrointestinal tract $\mathrm{N}$ that returned to the ornithine-urea cycle remained constant, i.e. there was no regulation of UNS at all. Importantly, though, in this study there were altered amounts of feed intake (compared with the changing of $\mathrm{N}$ intake with isoenergetic diets used in the other studies), which may explain the differences observed.

As alluded to earlier, it is believed that UNS increases in ruminants at times when $\mathrm{N}$ demands are increased, for example during pregnancy and lactation (Houpt \& Houpt, 
1968). Interestingly, it has been reported in sheep that rumen ammonia concentration increases in both pregnant and lactating animals compared with non-pregnant controls (Benlamlih \& de Pomyers, 1989), presumably due to increased urea hydrolysis. This occurs in conjunction with a $15 \%$ increase in rumination time and a $30-40 \%$ decrease in renal urea excretion (Benlamlih \& de Pomyers, 1989), suggesting that microbial urea metabolism increases in line with the demands of the host.

Finally, there is an additional benefit of the UNS process in ruminants. The salvaging of urea in the gastrointestinal tract also reduces the need for urea excretion via the kidneys, and hence may help conserve water. This is especially important for ruminants that inhabit a dry environment (for example, camels). Interestingly, the percentage of urea synthesised that enters the gastrointestinal tract is extremely high in desert animals. In camels 94$97 \%$ of the total urea synthesised enters the gut, in desert sheep $75 \%$, and in desert goats $79 \%$ (Mousa et al. 1983). Intriguingly, during periods of total water deprivation these levels increase even further to $94 \%$ in desert sheep and $95 \%$ in desert goats (Mousa et al. 1983). This suggests that increased breakdown of urea in the gut may help conserve water, presumably by reducing the need for urinary urea excretion and therefore water loss.

In summary, UNS has been extensively demonstrated in ruminants and the consensus is that it is beneficial to the host animal. This fact has been capitalised on by the incorporation of urea into feeds. On the whole, it appears that UNS is a regulated process although it is also very dependent on the type of diet ingested. The nature of the control mechanism has yet to be fully resolved, but may involve several organs including salivary gland, kidney and rumen, and specific urea transporter proteins.

\section{Non-ruminants}

In contrast to ruminants, there is less known about UNS in non-ruminant animals, such as mice and rats. In ruminant animals, the most important organ in $\mathrm{N}$ metabolism is the rumen, which is anterior to the major absorptive organ, the duodenum. As the name suggests, non-ruminants lack a rumen or rumen-like organ anterior to the small intestine (Hill \& Cook, 1986). This fact in itself has major implications for UNS when considering the fate of bacterially derived products such as amino acids. In nonruminants, the majority of urease-containing bacteria live in the large intestine - the caecum and colon. Hence, the 'traditional' view was that since the majority of nutrient absorption occurred in the small intestine and the majority of intestinal bacteria live in the caecum and colon, UNS has little, if any, role in non-ruminant animals. Certainly, procedures such as dietary urea supplementation do not appear to benefit some non-ruminants, such as the horse (Martin et al. 1996), to the same extent as ruminants.

To establish whether UNS is present in non-ruminants several basic criteria must be satisfied. Urea must be able to enter the gut, ideally where the bacteria reside. Urea breakdown should occur and the products of this breakdown or bacterially derived metabolites should be absorbed. We will now present evidence relating to these criteria.
Because the large intestine has been identified as the major repository of gut bacteria, this has been the focal point for a majority of the studies we will present. However, it should be noted that more recent research has demonstrated the existence of bacteria in the small intestine of non-ruminant species, such as dogs (Buddington, 2003) and mice (Hooper et al. 2001).

The idea of a role for the colon in non-ruminant UNS is supported by the demonstration of a significant flux of labelled urea across both the proximal and distal rat colon (mean clearance 5 (SE 1) $\mu \mathrm{l} / \mathrm{min}$ per $\mathrm{g}$ ), while values for labelled mannitol were not significantly different from zero (Fihn \& Jodal, 2001). We have also shown that urea transporters are present in the mouse colon and that the plasma membranes of colonocytes possess functional urea transporters (Stewart et al. 2004). This means a specific pathway by which urea could enter the colonic lumen of a non-ruminant animal exists in the colon. Urea breakdown has also been shown to occur in the caecum and/or colon of non-ruminants (Hill \& Cook, 1986) - for example, dogs (LeVeen et al. 1978) and rats (Harada et al. 1985). Indeed, the major source of $\mathrm{N}$ in the colon of non-ruminant animals is thought to be the ammonium ions derived from urea (Mason, 1984).

In the 1980s, investigation of the urea kinetics of a nonruminant animal, the dog, showed that there was a recycling of labelled ammonia back into urea, suggesting ammonia-N was reabsorbed by the host (Wolfe, 1981). Interestingly, this recycling of ammonia was reduced by treatment with antibiotics (Wolfe, 1981). In another study in rats, Torrallardona and colleagues (1996a) showed microbialderived lysine was utilised by the host and that in gnotobiotic (germ-free) animals this was absent. In a further report, Torrallardona et al. (2003) showed in pigs that gastrointestinal microflora contributed significantly to the essential amino acid requirements. However, the site of amino acid absorption was not resolved. Taken together, these data suggest that the basic components required for UNS are present in the non-ruminant large intestine.

By comparing the percentage of urea produced that is not excreted in the urine (i.e. urea that is available for hydrolysis in the gut) between species, an indication of the relative degree of UNS can be obtained. Under conditions of reduced protein intake, between 60 and $70 \%$ of the urea synthesised is not excreted via the kidney in sheep (Sarraseca et al. 1998). This proportion is $55-85 \%$ in cattle (Bunting et al. 1989a; Archibeque et al. 2001), whereas it is generally much lower in non-ruminants - for example, $20 \%$ in rats (Younes et al. 1996) and $15 \%$ in cats (Russell et al. 2000). The latter observation is of interest because it illustrates that even animals that consume an $\mathrm{N}$ rich diet, such as the domestic cat (Felis silvestris catus), have the capacity to salvage urea to a small extent although unless protein is restricted, only about $10 \%$ of the urea produced enters the gut (Russell et al. 2000).

In some species that practice coprophagy, it can be argued that bacterially derived amino acids are absorbed in the small intestine following ingestion of faeces. For example, prevention of coprophagy in rats greatly reduces the anabolism of microbial amino acids (Torrallardona et al. 1996b), suggesting the small intestine as the site of 
absorption. However, this would not explain the site of absorption in non-coprophatic species such as man.

\section{Man}

In recent times the evidence supporting UNS in man has begun to reach critical mass. Research has focused on identifying pathways of urea entry into the large intestine and on measuring the proportion of systemic urea that is cleaved and returned to the host.

The widespread use of molecular biology and the completion of the human genome have led to the identification of a candidate protein that transports urea and is expressed in the large intestine. We have identified a urea transporter in the human colon (hUT-A6) that was isolated from human colonic mucosa and is likely to mediate urea transport into the colon (Smith et al. 2004). Interestingly, this protein is activated by cAMP and may therefore serve to regulate urea flux into the colon.

Studies dating back to the 1950s indicate that urea hydrolysis, a pre-requisite to salvaging, occurred in man. Walser \& Bondenlos (1959) found that in normal men $20-30 \%$ of the urea produced was continuously being hydrolysed by intestinal bacteria and that this urea breakdown did not occur after antibiotic treatment. This value was later confirmed by several studies, including el-Khoury et al. (1994) who estimated bacterial urea breakdown to be $20-25 \%$ of total urea production. It was suggested by Wrong (1971) that the major site of urea hydrolysis in man was the colon, though it was reported to also take place in the mouth and stomach.

Urea breakdown in the stomach has become the focus of research in the last two decades because of the discovery of a urease containing pathogenic bacteria Helicobacter pylori. In the 1990s it was discovered that this bacteria causes ulceration of the stomach (Vaira et al. 1990) and is also implicated in tumorigenesis (Correa, 1992). The fact that infection by this bacteria depends on its capacity to cleave urea means that it may contribute to UNS, although any small benefits the host may gain are far outweighed by the bacteria's deleterious effects.

Significant amounts of amino acids of microbial origin have been detected in human subjects (Metges et al. 1999). Up to $20 \%$ of host lysine (about $70 \mathrm{mg} / \mathrm{kg}$ per d) may be derived from intestinal microbial sources (Metges, 2000). Studies with labelled urea have demonstrated that amino acids synthesised by intestinal bacteria using urea as an $\mathrm{N}$ source are indeed absorbed by the host (Tanaka et al. 1980; Jackson, 1998; Metges et al. 1999). Interestingly, both small and large intestines have been implicated in the relationship between the host $\mathrm{N}$ metabolism and intestinal microflora, with microbial amino acids being found in the blood plasma of both normal men and ileostomates (Metges et al. 1999). It appears that the majority of microbial lysine uptake takes place in the small intestine, with the possibility of some additional uptake in the colon (Metges, 2000). However, these reports also stated that without better understanding of the interactions between the intestinal mucosa and the microflora that inhabit the intestinal lumen and walls, the significance of these bacterially derived amino acids to overall $\mathrm{N}$ balance cannot be stated with any certainty (Metges et al. 1999).

Low nitrogen supply. The idea of urea salvaging in man became popular in the 1960s and early 1970s (Wrong, 1967; Wolpert et al. 1971; Richards, 1972; Bown et al. 1975), but the lack of dramatic effects low-protein diets had on the process dulled the scientific community's interest (Jackson, 1994). However, recent compelling evidence suggests that UNS is important in man in situations of low $\mathrm{N}$ intake (Jackson, 1995; Metges et al. 1999; Waterlow, 1999).

The introduction of studies utilising stable-isotope N-labelled urea has led to a resurgence of interest. Oral administration of stable-isotope N-labelled urea $\left({ }^{15} \mathrm{~N}^{15} \mathrm{~N}\right)$ is a useful method for investigating the fate of gastrointestinal urea in man. Labelled urea that is not broken down by bacterial urease remains as ${ }^{15} \mathrm{~N}^{15} \mathrm{~N}$. In contrast, ammonia formed as a breakdown product will contain just one ${ }^{15} \mathrm{~N}$ molecule. If this is reabsorbed, either directly or as microbial amino acids or peptides, then any future urea produced using this molecule will now contain an unlabelled and a labelled $\mathrm{N}$ molecule $\left({ }^{14} \mathrm{~N}^{15} \mathrm{~N}\right)$. Comparing the amounts of different urea species therefore indicates the overall fate of gastrointestinal urea (Lapierre \& Lobley, 2001). For example, experiments using orally administered ${ }^{15} \mathrm{~N}$-labelled urea showed that ${ }^{15} \mathrm{~N}$ incorporation was greater in Japanese subjects fed a low-protein diet $(0.5 \mathrm{~g} / \mathrm{kg}$ per d) than those on a normal diet (Tanaka et al. 1980). In addition, it was found that adult Papua New Guinea highlanders, whose typical diet was relatively low in protein, retained more ${ }^{15} \mathrm{~N}$ than Japanese adults consuming a normal diet (Tanaka et al. 1980). Indeed, evidence from one study suggests that only $10-20 \%$ of $\mathrm{N}$ derived from urea hydrolysis returns directly to urea formation (Jackson, 1998).

In men, $35 \mathrm{~g}$ protein/d represents the minimum physiological intake to maintain $\mathrm{N}$ balance. Reducing protein intake to $35 \mathrm{~g} / \mathrm{d}$ was found to decrease the amount of urea-N excreted in the urine from $54 \%$ to $36 \%$ of total urea production (Langran et al. 1992). The authors suggested that the increased proportion of urea passing into the gut and the resulting maintenance of urea hydrolysis was part of a regulated UNS process. Taking into account provisos concerning interpretation, this could suggest that in conditions where urea production and urinary excretion are significantly reduced, adaptive changes occur to maximise the amount of urea salvaged from the gut. Another study looked at the effects of feeding a diet of $30 \mathrm{~g}$ protein/d. Under these conditions, $\mathrm{N}$ balance could not be maintained and urea excretion was actually greater than observed with the $35 \mathrm{~g} / \mathrm{d}$ diet (Danielsen \& Jackson, 1992). Taken together these data may indicate that UNS appears to be able to compensate for reductions in $\mathrm{N}$ intake, but within limits. Additionally, feeding urea to men consuming diets marginally inadequate for protein was shown to compensate for low protein intake (Meakins \& Jackson, 1996).

It is important to note, however, that some reports completely contrast these findings. For example, a recent study observed no adaptive changes in urea kinetics during periods of starvation or low energy $(2.55 \mathrm{MJ} / \mathrm{d})$ diet, with no 
changes in the proportion of urea being hydrolysed in the gastrointestinal tract (20-25\%; Faber et al. 2003).

High nitrogen demand. In addition to studies investigating UNS during reduced $\mathrm{N}$ supply, several studies have investigated UNS in situations of increased $\mathrm{N}$ demand including infant growth and pregnancy. Before considering these it is important to mention that human growth rates are much less dramatic than in other species, though nevertheless evidence supporting changes in UNS are apparent.

Urea is present in human breast milk (Wu et al. 2000), where it contributes about $15 \%$ of the $\mathrm{N}$ content (Donovan \& Lonnerdal, 1989; Wheeler et al. 1991). Interestingly, the amount urea may be altered by changes in the maternal diet - for example, a decrease in the level of urea in milk - was reported when maternal dietary protein was decreased from $20 \%$ to $8 \%$ (Forsum \& Lonnerdal, 1980). It has been proposed that urea is a valuable source of $\mathrm{N}$ for neonates and there is indeed evidence that substantial hydrolysis of urea occurs in the neonatal colon (Wheeler et al. 1991). The reported rate of urea hydrolysis by colonic microflora in breast-fed infants has been found to be higher in those under 6 weeks old compared with older infants (Steinbrecher et al. 1996). This led the authors to suggest that UNS is particularly important in the first few weeks of life.

Urea hydrolysis in the gastrointestinal tract of infants has been shown to increase the supply of certain amino acids, including lysine (Millward et al. 2000). Millward et al. (2000) also reported that about $50 \%$ of all urea produced in these infants was hydrolysed in the gut, compared with the 20-25\% reported in adults (Long et al. 1978; el-Khoury et al. 1994). More interestingly, infant Papua New Guinea highlanders retained a significantly larger amount of ${ }^{15} \mathrm{~N}$ labelled urea than their parents (Tanaka et al. 1980). These results suggest that UNS is more active in children than adults, including populations where a low-protein diet requires enhanced levels of salvaging. It has been suggested that the marginal protein intake that occurs during breastfeeding could be one possible explanation for this increased UNS in infants (Heine et al. 1991). The obvious conclusion to be drawn is that children, especially very young infants, have significantly higher levels of UNS compared with adults, presumably because $\mathrm{N}$ demands for growth are so high.

Another situation when $\mathrm{N}$ demand is increased is during pregnancy, when both the mother and fetus require large amounts of $\mathrm{N}$. Although dietary $\mathrm{N}$ intake increases during pregnancy, measurements of urea production and excretion suggest UNS also increases (Forrester et al. 1994). Interestingly, the highest salvaging values occur in the first trimester (about $80 \mathrm{mg} \mathrm{N} / \mathrm{kg}$ per d compared with about $40 \mathrm{mg} \mathrm{N} / \mathrm{kg}$ per $\mathrm{d}$ in non-pregnant women), when protein intake is not as great as at later stages in the pregnancy (Forrester et al. 1994). Since this coincides with the period when fetal growth is slowest, perhaps these data suggest that increased UNS helps to satisfy maternal $\mathrm{N}$ demands rather than fetal requirements. Another report showed that urea excretion decreases between week 16 and week 24 of pregnancy (McClelland et al. 1997), perhaps indicating an increase in UNS. The same study showed that lowering the protein content of the diet, at any point during pregnancy, increases urea hydrolysis and salvaging as would be expected (McClelland et al. 1997).

Although highly speculative, it is worth noting that sudden infant death syndrome (SIDS) has been connected with colonic bacterial urease activity. One report has detailed that the faecal contents of infants who had died of SIDS, also known as 'cot death', differed from those of other unexpected infant deaths (Wiklund et al. 1998). SIDS subjects had low faecal urease activity and unmetabolised faecal urea, compared with the high urease activity and lack of urea found in control subjects (Wiklund et al. 1998). It was proposed that the unmetabolised urea in SIDS subjects leads to metabolic alkalosis and a subsequent respiratory insufficiency, resulting in infant death. Currently, it remains controversial whether these changes in urea metabolism would be sufficient to cause such marked changes in $\mathrm{pH}$, with both sides of the argument passionately supported. Nevertheless, the suggestion remains that the mechanisms in the infant colon that transport urea to colonic bacteria may, in some situations, actually lead to fatal consequences if the urea is not actually broken down by the bacterial urease enzyme.

Finally, it has been proposed that an added bonus of the UNS process is the maintenance of a 'healthy' large intestine microflora population. These resident bacteria may guard against invasion of pathogenic bacteria and colonic neoplasia (Gibson et al. 2002; Isolauri et al. 2002). It is known that anaerobic bacterial fermentation in the colon produces short-chain fatty acids, such as butyrate, that are used by colonic cells and thought to help prevent cancer (Hinnebusch et al. 2002). It has also been suggested that colonic bacteria may aid normal digestion, and the fact that germ-free experimental animals have higher energy requirements (Heine et al. 1987) is certainly an intriguing observation.

In summary, there is a growing body of evidence suggesting that UNS does indeed occur in man and that it may be a regulated process. There is also evidence indicating that UNS plays an active role in maintaining $\mathrm{N}$ balance in man under certain situations.

\section{What are the molecular mechanisms involved in urea salvage?}

The question as to whether UNS is simply a consistent part of the $\mathrm{N}$ transfer processes or a regulated process sensitive to host $\mathrm{N}$ balance remains to be fully answered, but a substantial amount of evidence suggests that it may indeed be the latter. A regulated process would be expected to consist of a mechanism for regulating the supply of urea from host to bacteria and/or for regulating the movement of the endproducts of the process, namely ammonia, amino acids and peptides, from bacteria to host. A basic hypothetical model of the components of the UNS mechanism is shown in Fig. 2. The governors of this system are the specialised transporters that are proposed to be regulated depending upon nutritional requirements. There are a number of points during UNS where distinct, regulated transporters could play a role - including urea transporters, ammonia transporters and amino acid transporters. The evidence supporting the presence of these specialised 
proteins in the mammalian gastrointestinal tract is presented below.

\section{Urea transport}

In order for UNS to occur, urea must pass into the gastrointestinal tract. As previously stated, although urea is present in the saliva of all mammals, the majority enters across the gastrointestinal tract wall. There are several possible mechanisms by which urea can cross an epithelial layer. The traditional view was that urea is freely permeable across cell membranes, via passive lipid-phase diffusion (Galluci et al. 1971). This may indeed account for a small amount of urea movement into the gastrointestinal tract. However, plasma membranes are relatively impermeable to urea and, following the discovery of specialised urea transporter proteins, the favoured mechanism is for urea to move via a carrier-mediated process.

Facilitative urea transporters. In the late 1980s, several functional studies convincingly showed that erythrocytes and terminal inner medullary collecting ducts of the kidney nephron possessed particularly high urea permeabilities, which were in fact too high to be explained by lipid diffusion alone (for a review, see Marsh \& Knepper, 1992). This suggested that urea could cross certain biological membranes by a carrier-mediated mechanism. The existence of specialised urea transporters was confirmed by the isolation from rabbit kidney inner medulla of a cDNA encoding a facilitative urea transporter, UT-A2, which interestingly was also very strongly expressed in the rabbit colon (You et al. 1993). Like all other facilitative urea transporters later cloned, this transporter allows rapid movement of urea down a concentration gradient, does not require the presence of $\mathrm{Na}$ ions, and is inhibited by phloretin. These proteins would therefore be well suited to transporting urea from the blood, where in man urea circulates at a concentration between 4 and $10 \mathrm{~mm}$, to the gastrointestinal tract. Since the latter contains ureametabolising bacteria, a concentration gradient exists favouring movement of urea into the gastrointestinal tract.

Facilitative urea transporters are derived from two distinct genes - UT-A (Slc14a2) and UT-B (Slc14al) (for reviews, see Smith \& Rousselet, 2001; Sands, 2003). Although the $U T-B$ gene gives rise to only one protein, UT-B, there are five well-known splice variants of the $U T-A$ gene (see Fig. 3). Four of these are predominantly expressed in the kidney - UT-A1, UT-A2, UT-A3 and UT-A4 - while a fifth, UT-A5, is found in the testis. A sixth isoform, UT-A6, has recently been characterised that contains a unique exon (see Fig. 3). In addition, it is now becoming apparent that facilitative transporters are present in numerous other tissues - including brain (Berger et al. 1998), and, importantly, the gastrointestinal tract (Timmer et al. 2001; Inoue et al. 2004; Stewart et al. 2004).

Facilitative urea transporters have been detected in ruminants. For example, cDNA has been isolated from sheep rumen that encodes a fragment of a urea transporter with $87 \%$ amino acid identity to rat UT-B (Ritzhaupt et al. 1998). This transporter is perhaps responsible for the phloretin-sensitive urea flux reported in sheep rumen by the same group (Ritzhaupt et al. 1997). UT-B urea transporters have also been found in the rumen of Holstein heifers and preliminary results show them to be differentially expressed depending upon dietary N content (Marini \& van Amburgh, 2003). In contrast, altering $\mathrm{N}$ intake did not affect the abundance of UT-B urea transporters located in sheep rumen (Marini et al. 2004). Although their precise role in ruminal urea transport remains to be elucidated, with even some suggestions for a possible involvement in the re-uptake of urea from the rumen, the regulation of urea transporters remains an intriguing possibility.

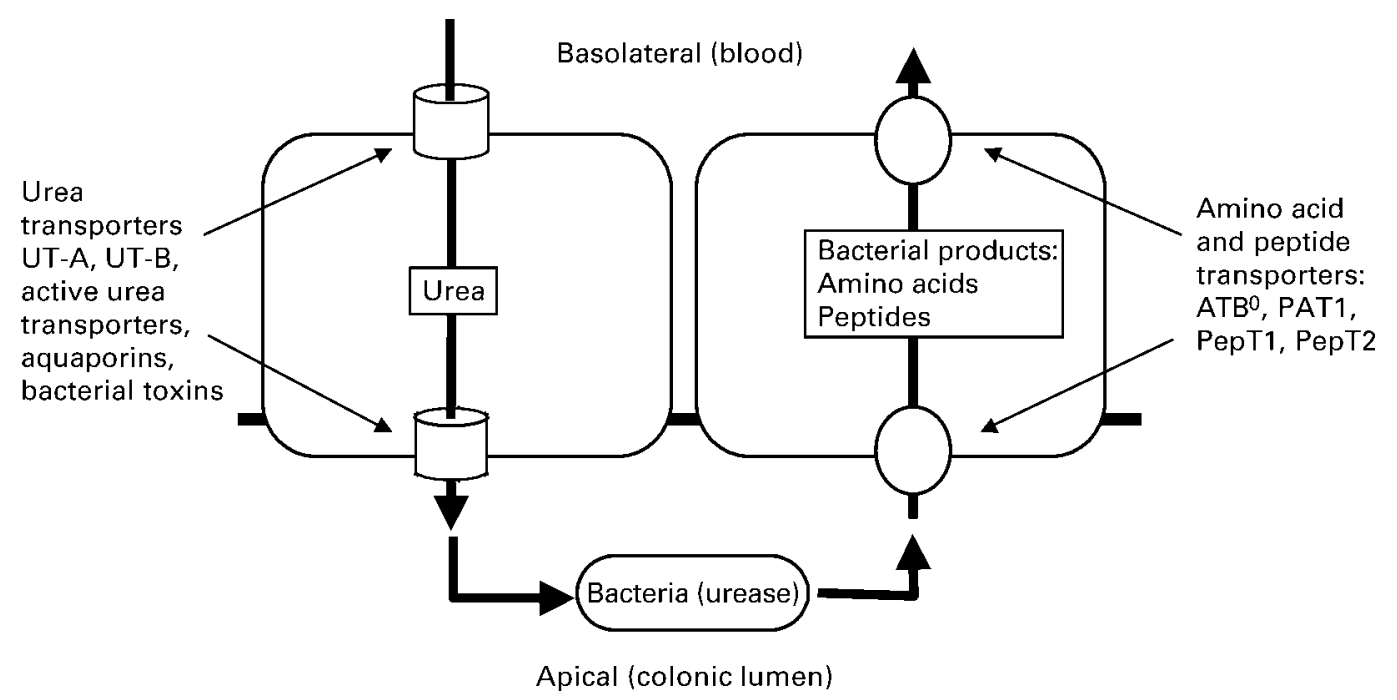

Fig. 2. Basic hypothetical model of components of the urea nitrogen salvaging mechanism. Urea transporters expressed in plasma membranes of colonic epithelia mediate urea flux from host to gastrointestinal lumen. Urease-containing colonic bacteria then catabolise urea, liberating ammonia and carbon dioxide. This action maintains a concentration gradient favouring urea flux into the gastrointestinal lumen. The ammonia is then either absorbed by the host or utilised by the bacteria for anabolic process. The products of bacterial synthesis, in the form of amino acids and nucleic acids, can also be taken up by the host via amino acid, peptide or as yet undefined transporters. 


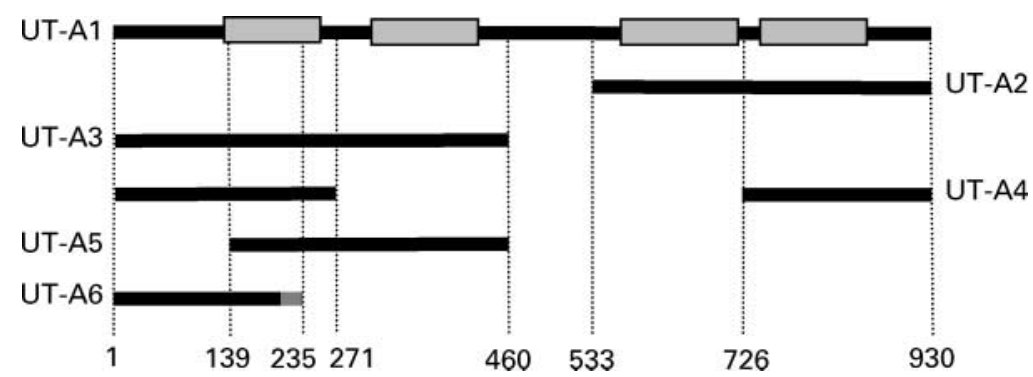

Fig. 3. Summary diagram of the UT-A urea transporter family. The basic structure of the characterised UT-A urea transporter isoforms is illustrated relative to the largest isoform, UT-A1. The horizontal black lines represent the different isoform proteins (UT-A1 to UT-A6), while the corresponding amino acid numbers in UT-A1 are shown at the bottom. The grey solid line in UT-A6 denotes the nineteen amino acids encoded in the unique exon $5 \mathrm{a}$.

In the rat, a number of different UT-A mRNA isoforms have been detected throughout the gastrointestinal tract (Doran et al. 1999). Both a $2 \mathrm{~kb}$ UT-B mRNA signal and a $50 \mathrm{kDa}$ UT-B protein has been detected in the rat colon (Bagnasco et al. 2003). In the same report, it was shown that in rats fed a low-protein diet $(8 \%)$ for $10 \mathrm{~d}$, colonic UT-B expression was surprisingly decreased $56 \%$ compared with rats fed a control diet (Bagnasco et al. 2003). This finding suggests that expression levels of facilitative urea transporters in the gastrointestinal tract can be regulated by changes in nutritional intake. Similar regulation of expression levels had previously been shown in renal tissue, where reduction in dietary protein levels (from $18 \%$ to $8 \%$ ) caused a significant increase in UT-A1 mRNA in the rat kidney medulla (Smith et al. 1995). This observation helped explain the increased phloretin-inhibitable urea transport observed in inner medullary collecting duct cells during low-protein diets (Isozaki et al. 1993). Further evidence of facilitative urea transporters in the non-ruminant gut has been found in the mouse colon. Several UT-A isoforms were localised to mouse colonic crypts (Stewart et al. 2004). Importantly, a phloretin-sensitive urea pathway was found to exist in colonic plasma membrane (Stewart et al. 2004) see Fig. 4. This pathway is therefore similar to those reported in other tissues, including kidney and testis, which express UT-A and UT-B proteins (Fenton et al. 2002).

Facilitative urea transporters have also been found in human subjects. The structure of the human $U T-A$ gene has recently been resolved and mapped to the Slc $14 a 2$ gene locus (Bagnasco et al. 2001). As predicted from studies on other species, human UT-A1 is located in the inner medullary collecting duct, is inhibited by phloretin and is activated by cAMP (Bagnasco et al. 2001). The human colon has been shown to be permeable to urea (Moran \& Jackson, 1990). Interestingly, a cDNA isolated from human colon encoding a novel UT-A urea transporter human UT-A6 (Genbank Accession \#AK074236) has recently been characterised (Smith et al. 2004). Like other family members, human UTA6 is sensitive to phloretin and cAMP. Using hUT-A6 cDNA as a probe we have performed Northern analysis on human gastrointestinal tract mRNA and detected two transcripts of size 2.2 and $5.6 \mathrm{~kb}$ in the human colon (Fig. 5). Human UT-B transporters have also been found in erythrocytes (Olives et al. 1994) and endothelial cells of kidney descending vasa recta (Timmer et al. 2001). The presence of UT-B urea

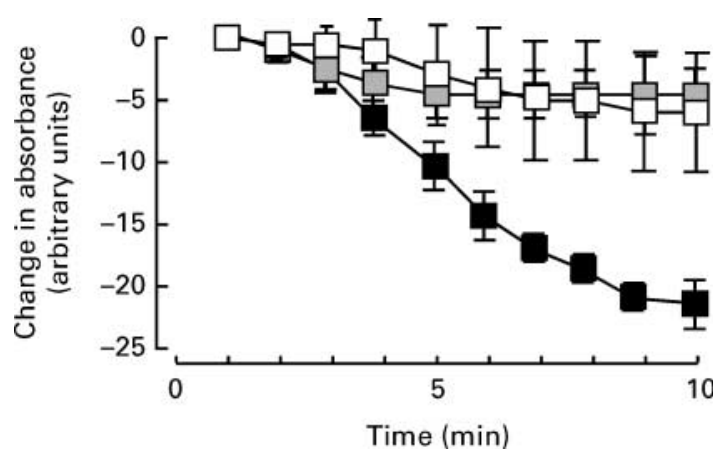

Fig. 4. Phloretin-inhibitable urea flux in the mouse colon. Results of refractive light experiments measuring urea flux in mouse colonic plasma membrane vesicle preparations. Vesicle swelling, represented by a decrease in absorbance readings, was significantly greater in $2 \mathrm{mM}$-urea $(\boldsymbol{\square})$ than in the control solution ( $\square$ ) $(P<0.05 ;$ ANOVA). This increase in swelling due to urea (i.e. a urea flux) was completely abolished in the presence of $500 \mu \mathrm{M}$-phloretin ( $\square)(P<0.05$; ANOVA), a known inhibitor of facilitative urea transporters. Mean values are shown, with standard errors represented by vertical bars.

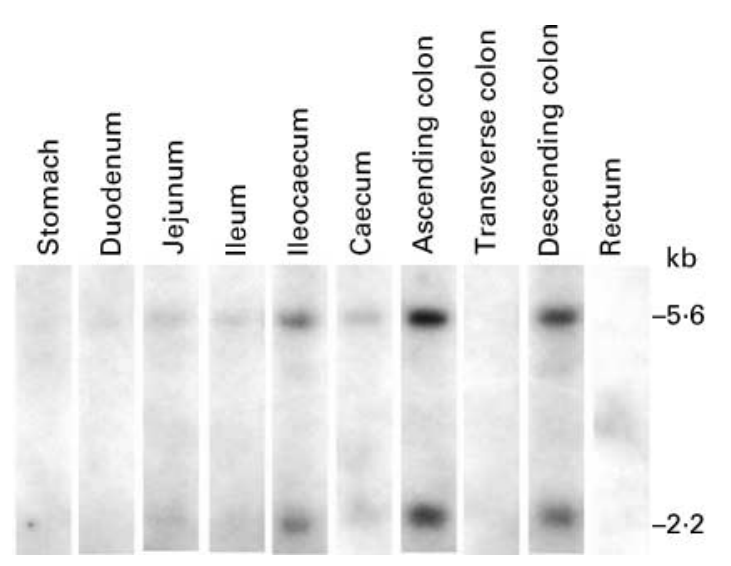

Fig. 5. Northern analysis of human gastrointestinal tract poly $\mathrm{A}^{+}$ RNA $(1 \mu \mathrm{g} / \mathrm{lane})$ probed with full-length hUT-A6. Northern blot, probed at medium stringency, showing strong signals at 2.2 and $5.6 \mathrm{~kb}$ in the ascending and descending colon - presumably representing hUT-A6. Weaker signals of the same size were present in jejunum, ileum, ileocaecum and caecum. 
transporters in the human gastrointestinal tract is now being fully investigated. Initially, an RT-PCR product with $82 \%$ identity with human UT-B was reported in the human colon (Ritzhaupt et al. 1998), while Northern blot analysis using a specific human UT-B probe detected 2.0 and $3.6 \mathrm{~kb}$ signals in human small intestine and colon (Olives et al. 1996). This has now been confirmed by the detection in the human colon of a $2.0 \mathrm{~kb}$ UT-B transcript and a $50 \mathrm{kDa}$ UT-B protein, which is localised to the epithelial layers of colonic crypts (Inoue et al. 2004). Interestingly, UT-B expression has also been displayed in an intestinal cell line, Caco-2, which possesses a phloretin-sensitive transepithelial urea flux (Inoue et al. 2004). If considered alongside functional data from the mouse, this provides compelling evidence that facilitated urea transporters are expressed in the colon of non-ruminant animals, including man, and that functionally these proteins play a role in urea transport across cellular plasma membranes. Intriguingly, studies in rat colon also suggest that regulation of these transporters may occur during changes in nutritional requirements.

Active urea transporters. Although cDNA encoding mammalian active urea transporters have not been isolated, functional data supporting the presence of these proteins transport in kidney inner medulla collecting ducts have been reported (Sands, 2003). In contrast to facilitative urea transport, active transport can move urea against a concentration gradient and requires the presence of $\mathrm{Na}$ ions (Sands, 2003). Several different transport activities have been characterised. These fall into two classes based on their sensitivity to phloretin. Active urea secretion and 'furosemide-induced' active urea absorption are inhibited by phloretin, whereas the carrier-mediated urea absorption activities induced by a 'low-protein diet' or 'hypercalcaemia' are not phloretin-inhibitable (Sands, 2003). Data also suggest the presence of both 'Na-urea co-transporters' and 'Na-urea counter transporters'.

In mammals, active urea transport has to date only been reported in the rat kidney (Kato \& Sands, 1998) and its presence in the intestinal tract of rats or other species has yet to be investigated. However, it is interesting to note that a low-protein diet was shown to induce active urea transport in rat initial inner medullary collecting ducts (Isozaki et al. 1994). Up regulation of urea transport via these transporters may in part be responsible for the decreased renal urea clearance observed in low-protein diets in ruminants (Marini \& van Amburgh, 2003), non-ruminants (Younes et al. 1996) and man (Langran et al. 1992). This would promote urea retention and may represent an integrated response between the kidneys and the gastrointestinal tract, geared to conserving and utilising urea as an $\mathrm{N}$ source. This could involve alterations in expression levels of both the active urea transporters, that have not yet been cloned, and facilitative urea transporters.

Other transporters. Aquaporins (AQP) are a large family of water transporters found in many different tissues, including the gastrointestinal tract (for a review, see Ma \& Verkman, 1999). The functional properties of these transporters vary considerably, and some members including AQP3, AQP7, AQP8 and AQP9 - are capable of transporting small amounts of urea (for a review, see Echevarria \& Ilundain, 1998). All four of these AQP have been detected in the colon and could therefore be involved in UNS mechanisms.

A number of other transporters belonging to the $\mathrm{Na}$ coupled solute transporters have been reported to be slightly permeable to urea, for example, the $\mathrm{Na}$-glucose cotransporter SGLT1 (Leung et al. 2000), and $\mathrm{Na-glutamate}$ co-transporter (MacAulay et al. 2002). Although it is well understood that expression levels of such transporters can be regulated by dietary intake, for example SGLT1 is regulated by dietary carbohydrate (Ferraris, 2001), little is known regarding any possible role in urea transport. Indeed, while some of these transporters are expressed in the colon, their urea permeabilities are dramatically lower than UT-A or UT-B transporters (for example, $1.3 \times 10^{-7} \mathrm{~cm} / \mathrm{s}$ for SGLT1 (Leung et al. 2000) compared with a value of $4.5 \times 10^{-5} \mathrm{~cm} / \mathrm{s}$ for the facilitative urea transporter UT-A2 (You et al. 1993)). Therefore, compared with the facilitative urea transporters, they may be expected to play only a very minor role in urea movement into the colon.

Bacterial toxins. An interesting possibility is that the bacteria themselves secrete factors that permeabilise the membrane allowing urea to pass. A recent report showed that the H. pylori Vac A toxin may act as a urea permease, promoting urea diffusion across epithelia and enabling H. pylori to infect the stomach (Tombola et al. 2001). It is therefore plausible that resident colonic bacteria secrete 'toxins' that act directly on intestinal epithelial layers, promoting bacterial growth by increasing the movement of urea into the gut lumen. Another intriguing yet untested possibility is that bacterial toxins may induce expression of host proteins, for example, facilitative urea transporters, and in so doing increase the supply of urea.

\section{Reabsorption of nitrogen}

As we have described earlier, there is evidence indicating that UNS occurs in non-ruminant animals, including man. In terms of the process of UNS, for the host to gain access to the urea- $\mathrm{N}$ liberated by the action of bacterial urease, there is a need for proteins capable of transporting the products of bacterial metabolism, i.e. ammonia, amino acids or peptides. Crucially, investigation is required to determine whether post-ileal areas of the gut that are not usually associated with the uptake of these substances, specifically the colon, also contribute to bacterial product transport.

There are no detailed studies of ruminant colonic ammonia transport, but it is suggested that roughly half of the overall $\mathrm{N}$ uptake in the ruminant gut is in the form of ammonia (Lapierre \& Lobley, 2001), though this varies depending upon diet. The uptake of ammonia in ruminants has been linked with short-chain fatty acids (Bodeker et al. 1992) and a K-coupled transport system has also been suggested (Bodeker \& Kemkowski, 1996). Ammonia transport in non-ruminants has been demonstrated in the equine colon, which although impermeable to amino acids, transports ammonia (Bochroder et al. 1994). In rats, ammonium permeates the colon through $\mathrm{Na}-\mathrm{K}-2 \mathrm{Cl}$ cotransporters (probably via the $\mathrm{NKCC} 1$ isoform) and $\mathrm{Na}-\mathrm{H}$ 
exchangers (Ramirez et al. 1999). In contrast, the apical membrane of rabbit colon has a very low permeability to both ammonia and ammonium ions (Singh et al. 1995). The human colon is known to be permeable to ammonia (Bown et al. 1975) and approximately $9 \mathrm{~g}$ ammonia are absorbed per d (Wrong, 1978). Ammonia transport may be aided by the secretion of bicarbonate ions by the colonic mucosa, allowing the conversion of ammonium ions to ammonia near the apical membrane and hence allowing it to be more readily absorbed (Wrong, 1978).

Amino acid transporters have been localised throughout the gastrointestinal tracts of ruminants, including the colon (Howell et al. 2001). It is also now known that $\mathrm{Na}$-dependent, chloride-dependent amino acid transporters $\left(\mathrm{ATB}^{0,+}\right)$, which can transport neutral and cationic amino acids, are expressed in the mouse colon (Hatanaka et al. 2002). One study using ${ }^{3} \mathrm{H}$-labelled glycine suggested that mouse $\mathrm{ATB}^{0,+}$ transporters absorb amino acids from the contents of the colon (Ugawa et al. 2001). The mPAT1 proton-dependent amino acid co-transporter is also highly expressed in the mouse colon (Boll et al. 2002). Interestingly, alanine absorption (mean 130 (SE 15) $\mu \mathrm{mol} / \mathrm{h}$ per $\mathrm{g}$ ) has been measured in the fetal rat colon (Potter et al. 1983). This finding indicates that the fetal colon may function to help meet nutritional requirements, possibly involving bacterial-derived amino acids. In the human colon, although direct absorption of amino acids remains a possibility, there are as yet no reports of specific amino acid transporters being present. Indeed, the nutritional benefit of absorbed bacterial-derived amino acids has yet to be established in human subjects (Metges, 2000).

Peptide transporters have also been localised to the mammalian colon, although there is again great species variability. The peptide transporter PepT1 has not been detected in the colon of ruminant animals, such as sheep and cows (Chen et al. 1999). In the non-ruminant rat, PepT1 protein has been detected in the colon, but only in the first week after birth (Shen et al. 2001). However, another report using RT-PCR detected PepT1 in the adult rat colon (Herrera-Ruiz et al. 2001). PepT2 has also been detected in the rabbit colon (Doring et al. 1998). Importantly, although expressed at a lower level than in the small intestine, PepT1 is expressed in the adult human colon and may be the pathway for colonic $\mathrm{N}$ absorption (Ford et al. 2003). Interestingly, colonic human PepT1 is known to be up regulated in cases of chronic inflammation of the colon (Merlin et al. 2001) and in patients with short-bowel syndrome (Ziegler et al. 2002). In addition, up regulation of human PepT1 has been reported in the jejunum during starvation (Ogihara et al. 1999). Other peptide transporters, such as PTR3, PHT1 and HPT-1, have also been shown to be present in the human colon (Herrera-Ruiz et al. 2001). Taken together these observations indicate at least the possibility that colonic peptide transporters may be regulated by dietary intake and may play a significant role in UNS, although there is as yet no direct evidence.

An in-depth discussion of these processes is beyond the scope of the present review, but suffice to say that the components for a complete UNS process are present in most species so-far studied. In addition, the expression of some of these transporters is regulated in situations of altered nutritional requirements (for example, down regulation of gastrointestinal UT-B urea transporters during low-protein diets (Bagnasco et al. 2003), up regulation of peptide transporters in the human jejunum during starvation (Ogihara et al. 1999)). Another intriguing possibility is that differences in expression of these transporter systems underlie the species differences observed for UNS. For example, sheep can convert digestible $\mathrm{N}$ to absorbed amino acid-N much better than cattle are able to (Lapierre \& Lobley, 2001). Is there an explanation for this difference at the molecular level? Currently no, but in the future this knowledge offers the prospect of improving $\mathrm{N}$ utilisation in cattle.

In summary, it therefore remains highly plausible that UNS is not just simply an effect of the microbial environment, but a specific, regulated interaction between the gut bacteria and their host. However, there is a need for studies that profile transcripts and the expression of proteins that are potentially involved in UNS, particularly in the caecum and colon. Ideally, experiments should be performed under conditions known to promote UNS (for example, low-protein diets, growth).

\section{Conclusions}

In mammals, $\mathrm{N}$ balance can be maintained throughout fluctuations in dietary intake. There is now compelling evidence to suggest that a contributory factor to this is the process of UNS. Evidence for the salvaging of urea-N has been found in gastrointestinal tracts of both ruminant and non-ruminant animals, including man. As expected, on a day-to-day basis, UNS appears more important in ruminant animals (for example, sheep, cattle) than in man. However, there are a number of situations where substantial UNS may occur in man, including ingestion of low-protein diets, during periods of growth and during pregnancy.

The exact mechanisms of UNS are not yet fully understood. Precisely how urea passes into the gastrointestinal tract, and by which pathways bacterial-derived ammonia, amino acids and/or peptides are reabsorbed is still unclear. Nevertheless, it is evident that such processes may be regulated by nutritional demands, in that several studies have reported an increased UNS when there is a decrease in protein intake. The role of UNS in maintaining commensal bacteria populations and the resulting benefits this brings are also not to be underestimated. In the present review, we have summarised studies discussing a variety of transporters that may be implicated in the UNS process. Further work is now required to investigate the specific role of facilitative urea transporters, AQP, amino acid transporters, peptide transporters and possibly other proteins. Clearly, the most obvious step is to look at the effects of low-protein diets, pregnancy and illness on the expression of these transporters throughout the gastrointestinal tract, especially in the non-ruminant colon. Functional assays of any corresponding changes in the urea flux from these regions of the gut are also required. Another interesting area for further research would be to investigate the effect of removing the intestinal bacteria, i.e. how is $\mathrm{N}$ metabolism affected in germ-free animals? The possible involvement of a breakdown in the UNS process in the colons of SIDS victims is another area worthy of further study. Through 
studies such as these, we can gain a better understanding of the process of UNS and how it may affect our daily lives.

What are the future implications of this work? The significance and relevance of UNS to the wellbeing of mammals, including man, is potentially far reaching. Taking a step back, the relationship between host and commensal micro-organisms is poorly understood and additional knowledge would undoubtedly have a broad appeal. A complete knowledge of this and the UNS process would enable clinical intervention in a variety of important situations. Possibilities include improving the nutritional benefit of low-protein diets, aiding child growth, improving the health of pregnant women, and possibly even helping tackle the problem of cot death.

\section{Acknowledgements}

We would like to acknowledge the BBSRC and the Royal Society for funding this work.

\section{References}

Al-Dehneh A, Huber JT, Wandeley R, Theurer CB, Pessarakli M \& de Young D (1997) Incorporation of recycled urea-N into ruminal bacteria flowing to the small intestine of dairy cows fed a high-grain or high-forage diet. Animal Feed Science and Technology 68, 327-388.

Archibeque SL, Burns JC \& Huntington GB (2001) Urea flux in beef steers: effects of forage species and nitrogen fertilization. Journal of Animal Science 79, 1937-1943.

Bagnasco SM, Jackson S, Vikulina T, Kim D-G, Hennigar RA \& Inoue H (2003) The UT-B urea transporter is expressed in colon mucosa. Journal of American Society of Nephrology Proceeding Abstract F-P0043.

Bagnasco SM, Peng T, Janech MG, Karakashian A \& Sands JM (2001) Cloning and characterization of the human urea transporter UT-A1 and mapping of the human Slc14a2 gene. American Journal of Physiology 281, F400-F406.

Bankir L (1996) Urea and the kidney. In The Kidney, chapter 14, pp. 571-606 [BM Brenner, editor]. Philadelphia: WB Saunders.

Benlamlih S \& de Pomyers H (1989) Changes in endogenous urea recycling and the handling of renal urea in pregnant and lactating Sardi sheep kept on a constant feeding level. Reproductive Nutritional Development 29, 129-137.

Berger UV, Tsukaguchi H \& Hediger MA (1998) Distribution of mRNA for the facilitated urea transporter UT3 in the rat nervous system. Anatomical Embryology 197, 405-414

Bochroder B, Schubert R \& Bodeker D (1994) Studies on the transport in vitro of lysine, histidine, arginine and ammonium across the mucosa of the equine colon. Equine Veterinary Journal 26, 131-133.

Bodeker D \& Kemkowski J (1996) Participation of $\mathrm{NH}_{4}{ }^{+}$in total ammonia absorption across the rumen epithelium of sheep (Ovis aries). Comparative Biochemical and Physiological Animal Physiology 114, 305-310.

Bodeker D, Shen Y, Kemkowski J \& Holler H (1992) Influence of short chain fatty acids on ammonia absorption across the rumen wall in sheep. Experimental Physiology 77, 369-376.

Boll M, Foltz M, Rubio-Aliaga I, Kottra G \& Daniel H (2002) Functional characterization of two novel mammalian electrogenic proton-dependent amino acid cotransporters. Journal of Biological Chemistry 277, 22966-22973.

Bown RL, Gibson JA, Fenton JC, Snedden W, Clark ML \& Sladen GE (1975) Ammonia and urea transport by the excluded human colon. Clinical Science of Molecular Medicine 48, 279-287.
Buddington RK (2003) Postnatal changes in bacterial populations in the gastro-intestinal tract of dogs. American Journal of Veterinary Research 64, 646-651.

Bunting LD, Boling JA \& MacKown CT (1989a) Effect of dietary protein level on nitrogen metabolism in the growing bovine: I Nitrogen recycling and intestinal protein supply in calves. Journal of Animal Science 67, 810-819.

Bunting LD, Boling JA, MacKown CT \& Davenport GM (1989b) Effect of dietary protein level on nitrogen metabolism in the growing bovine: II Diffusion into and utilization of endogenous urea nitrogen in the rumen. Journal of Animal Science 67, $820-826$.

Chen H, Wong EA \& Webb KEJ (1999) Tissue distribution of a peptide transporter mRNA in sheep, dairy cows, pigs and chickens. Journal of Animal Science 77, 1277-1283.

Correa P (1992) Human gastric carcinogenesis: a multistep and multifactorial process. Cancer Research 52, 6735-6740.

Danielsen M \& Jackson AA (1992) Limits of adaptation to a diet low in protein in normal man: urea kinetics. Clinical Science $\mathbf{8 3}$, $103-108$.

Donovan SM \& Lonnerdal B (1989) Non-protein nitrogen and true protein in infant formulas. Acta Paediatrica Scandinavica 78, 497-504.

Doran JJ, Gunn RB, Sands JM \& Timmer RT (1999) Urea transporter (UT-A) mRNA isoforms are expressed in rat extrarenal tissues. Journal of the American Society of Nephrology 10, 14A, A0069.

Doring F, Walter J, Will J, Focking M, Boll M, Amasheh S, Clauss W \& Daniel H (1998) Delta-aminolevulinic acid transport by intestinal and renal peptide transporters and its physiological and clinical implications. Journal of Clinical Investigation 101, 2761-2767.

Echevarria M \& Ilundain AA (1998) Aquaporins. Journal of Physiological Biochemistry 54, 107-118.

el-Khoury AE, Fugakawa NF, Sanchez M, Tsay RH, Gleason RE, Chapman TE \& Young VR (1994) Validation of the tracerbalance concept with reference to leucine: $24-\mathrm{h}$ intravenous tracer studies with $\mathrm{L}-\left[1-{ }^{13} \mathrm{C}\right]$ leucine and $\left[{ }^{15} \mathrm{~N}-{ }^{15} \mathrm{~N}\right]$ urea. American Journal of Clinical Nutrition 59, 1000-1011.

Ergene N \& Pickering EC (1978) The effects of reducing dietary nitrogen and of increasing sodium chloride intake on urea excretion and reabsorption and on urine osmolality in sheep. Quarterly Journal of Experimental Physiology 63, 67-76.

Faber P, Faber P, Johnstone AM, Gibney ER, Elia M, Stubbs RJ, Roger PL, Milne E, Buchan W \& Lobley GE (2003) The effect of rate and extent of weight loss on urea salvage in obese male subjects. British Journal of Nutrition 90, 221-231.

Fenton RA, Cooper GJ, Morris ID \& Smith CP (2002) Coordinated expression of UT-A and UT-B urea transporters in testis. American Journal of Physiology 282, C1492-C1501.

Ferraris RP (2001) Dietary and developmental regulation of intestinal sugar transport. Biochemical Journal 360, 265-276.

Fihn BM \& Jodal M (2001) Permeability of the proximal and distal rat colon crypt and surface epithelium to hydrophilic molecules. Pflugers Archives - European Journal of Physiology 441, 656-662.

Ford D, Howard A \& Hirst BH (2003) Expression of the peptide transporter hPepT1 in human colon: a potential route for colonic protein nitrogen and drug absorption. Histochemistry and Cell Biology 119, 37-43.

Forrester T, Badaloo A, Persaud C \& Jackson AA (1994) Urea production and salvage during pregnancy in normal Jamaican women. American Journal of Clinical Nutrition 60, 341-346.

Forsum E \& Lonnerdal B (1980) Effect of protein intake on protein and nitrogen composition of breast milk. American Journal of Clinical Nutrition 33, 1809-1813. 
Fuller MF \& Reeds PJ (1998) Nitrogen recycling in the gut. Annual Reviews of Nutrition 18, 385-411.

Galluci E, Micelli S \& Lippe C (1971) Non-electrolyte permeability across thin lipid membranes. Archives of Integrative Physiology and Biochemistry 79, 881-887.

Gibson GR, Mountzouris KC, McCartney AL \& Gibson GR (2002) Intestinal microflora of human infants and current trends for its nutritional modulation. British Journal of Nutrition 87, 405-420.

Harada K, Murawaki Y \& Hirayama C (1985) Comparative studies in nicotinohydroxamic acid and neomycin in ammonia and urea metabolism in rats. Research Communications in Chemical Pathology and Pharmacology 49, 309-312.

Harmeyer J \& Martens H (1980) Aspects of urea metabolism in ruminants with reference to the goat. Journal of Dairy Science 63, 1707-1728.

Hatanaka T, Huang W, Nakanishi T, Bridges CC, Smith SB, Prasad PD, Ganapathy ME \& Ganapathy V (2002) Transport of Dserine via the amino acid transporter ATB0, + expressed in the colon. Biochemical and Biophysical Research Communications 291, 291-295.

Heine W, Mohr C, Wutzke K \& Radke M (1991) Symbiotic interactions between colonic microflora and protein metabolism in infants. Acta Paediatrica Scandinavica 80, 7-12.

Heine W, Wutzke KD, Richter I, Walther F \& Plath C (1987) Evidence for colonic absorption of protein nitrogen in infants. Acta Paediatrica Scandinavica 76, 741-744.

Herrera-Ruiz D, Wang O, Gudmundsson OS, Cook TJ, Smith RL, Faria TN \& Knipp GT (2001) Spatial expression patterns of peptide transporters in the human and rat gastrointestinal tracts, Caco-2 in vitro cell culture model, and multiple human tissues. AAPS Pharmacological Science 3, E9.

Hill MJ \& Cook AR (1986) Nitrogen metabolism in the animal gut. Society of Applied Bacteriology Symposium 13, 287-301.

Hinnebusch BF, Meng S, Wu JT, Archer SY \& Hodin RA (2002) The effects of short-chain fatty acids on human colon cancer cell phenotype are associated with histone hyperacetylation. Journal of Nutrition 132, 1012-1017.

Hobson PN \& Wallace RJ (1982) Microbial ecology and activities in the rumen. Part I. Critical Review in Microbiology 9, $165-225$.

Hooper LV, Wong MH, Thelin A, Hansson L, Falk PG \& Gordon JI (2001) Molecular analysis of commensal host-microbial relationships in the intestine. Science 291, 881-884.

Houpt TR \& Houpt KA (1968) Transfer of urea nitrogen across the rumen wall. American Journal of Physiology 214, 1296-1303.

Howell JA, Matthews AD, Swanson KC, Harmon DL \& Matthews JC (2001) Molecular identification of high affinity glutamate transporters in sheep and cattle forestomach, intestine, liver, kidney, pancreas. Journal of Animal Science 79, 1329-1336.

Huntington GB (1986) Uptake and transport of non-protein nitrogen by the ruminal gut. Federation Proceedings 45, $2272-2276$.

Inoue H, Jackson SD, Vikulina T, Klein JD, Tomita K \& Bagnasco SM (2004) Identification and characterization of a Kidd antigen/UT-B urea transporter expressed in human colon. American Journal of Physiology 287, C30-C35.

Isolauri E, Kirjavainen PV \& Salminen S (2002) Probiotics: a role in the treatment of intestinal infection and inflammation? Gut 50, III54-III59.

Isozaki T, Gillin AG, Swanson CE \& Sands JM (1994) Protein restriction sequentially induces new urea transport processes in rat initial IMCD. American Journal of Physiology 266, F756-F761.

Isozaki T, Verlander JW \& Sands JM (1993) Low protein diet alters urea transport and cell structure in rat initial inner medullary collecting duct. Journal of Clinical Investigation $\mathbf{9 2}$ $2448-2457$.

Jackson AA (1994) Urea as a nutrient: bioavailability and role in nitrogen economy. Archives of Diseases in Childhood 70, 3-4.

Jackson AA (1995) Salvage of urea-nitrogen and protein requirements. Proceedings of the Nutrition Society 54, 535-547.

Jackson AA (1998) Salvage of urea-nitrogen in the large bowel: functional significance in metabolic control and adaptation. Biochemical Society Transactions 26, 231-236.

Kato A \& Sands JM (1998) Evidence for sodium-dependent active urea secretion in the deepest subsegment of the rat inner medullary collecting duct. Journal of Clinical Investigation 101, 423-428.

Koenig KM, Newbold CJ, McIntosh FM \& Rode LM (2000) Effects of protozoa on bacterial nitrogen recycling in the rumen. Journal of Animal Science 78, 2431-2445.

Koster HH, Woods BC, Cochran RC, Vanzant ES, Titgemeyer EC, Grieger DM, Olson KC \& Stokka G (2002) Effect of increasing proportion of supplemental $\mathrm{N}$ from urea in prepartum supplements on range beef cow performance and on forage intake and digestibility by steers fed low-quality forage. Journal of Animal Science 80, 1652-1662.

Langran M, Moran BJ, Murphy JL \& Jackson AA (1992) Adaptation to a diet low in protein: effect of complex carbohydrate upon urea kinetics in normal man. Clinical Science 82, 191-198.

Lapierre H \& Lobley GE (2001) Nitrogen recycling in the ruminant: a review. Journal of Dairy Science 84, Suppl., E223-E236

Leng L, Szanyiova M \& Boda K (1985) The renal response of sheep to a low dietary nitrogen intake. Physiologia Bohemoslovaca 35, 147-154.

Leung DW, Loo DD, Hariyama BA, Zeuthen T \& Wright EM (2000) Urea transport by cotransporters. Journal of Physiology 528, 251-257.

LeVeen EG, Falk G, Ip M, Mazzapica N \& LeVeen HH (1978) Urease as a contributing factor in ulcerative lesions of the colon. American Journal of Surgery 135, 53-56.

Long CL, Jeevanandam M \& Kinney JM (1978) Metabolism and recycling of urea in man. American Journal of Clinical Nutrition 31, 1367-1382.

Ma T \& Verkman A (1999) Aquaporin channels in gastrointestinal physiology. Journal of Physiology 517, 317-326.

MacAulay N, Gether U, Klaeke DA \& Zeuthen T (2002) Passive water and urea permeability of a human $\mathrm{Na}^{+}$glutamate cotransporter expressed in Xenopus oocytes. Journal of Physiology 542, 817-828.

McClelland IS, Persaud C \& Jackson AA (1997) Urea kinetics in healthy women during normal pregnancy. British Journal of Nutrition 77, 165-181.

Maekawa M, Beauchemin KA \& Christensen DA (2002) Chewing activity, saliva production and ruminal $\mathrm{pH}$ of primiparous and multiparous lactating dairy cows. Journal of Dairy Science $\mathbf{8 5}$, $1176-1182$.

Marini JC \& Van Amburgh ME (2003) Nitrogen metabolism and recycling in Holstein heifers. Journal of Animal Science 81, $545-552$.

Marini JC, Klein JD, Sands JM \& Van Amburgh ME (2004) Effect of nitrogen intake on nitrogen recycling and urea transporter abundance in lambs. Journal of Animal Science 82, 1157-1164.

Marsh MJ \& Knepper MA (1992) Renal handling of urea. In Handbook of Physiology, Renal Physiology, pp. 1317-1347 [EE Windhager, editor]. Oxford: Oxford University Press.

Martin RG, McMeniman NP, Norton BW \& Dowsett KF (1996) Utilization of endogenous and dietary urea in the large intestine of the mature horse. British Journal of Nutrition 76, 373-386. 
Mason VC (1984) Metabolism of nitrogenous compounds in the large gut. Proceedings of the Nutrition Society 43, 45-53.

Meakins TS \& Jackson AA (1996) Salvage of exogenous urea nitrogen enhances nitrogen balance in normal men consuming marginally inadequate protein diets. Clinical Science 90, 215-225.

Merlin D, Si-Tahar M, Sitaraman SV, Eastburn K, Williams I, Liu X, Hediger MA \& Madara JL (2001) Colonic epithelial hPepT1 expression occurs in inflammatory bowel disease: transport of bacterial peptides influences expression of MHC class 1 molecules. Gastroenterology 120, 1666-1679.

Metges CC (2000) Contribution of microbial amino acids to amino acids homeostasis of the host. Journal of Nutrition 130, $1857 \mathrm{~S}-1864 \mathrm{~S}$.

Metges CC, Petzke KJ, el-Khoury AE, Henneman L, Grant I, Bedri S, Regan MM, Fuller MF \& Young VR (1999) Incorporation of urea and ammonia nitrogen into ileal and fecal microbial proteins and plasma free amino acids in normal men and ilestomates. American Journal of Clinical Nutrition 70, 1046-1058.

Millward DJ, Forrester T, Ah-Sing E, Yeboah N, Gibson N, Badaloo A, Boyne M, Reade M, Persaud C \& Jackson AA (2000) The transfer of ${ }^{15} \mathrm{~N}$ from urea to lysine in the human infant. British Journal of Nutrition 83, 505-512.

Moran BJ \& Jackson AA (1990) ${ }^{15} \mathrm{~N}$ urea metabolism in the functioning human colon: luminal hydrolysis and mucous permeability. Gut 31, 454-457.

Mousa HM, Ali KE \& Hume ID (1983) Effects of water deprivation on urea metabolism in camels, desert sheep and desert goats fed dry desert grass. Comparative Biochemical and Physiological Anatomy 74, 715-720.

Ogihara H, Suzuki T, Nagamachi Y, Inui K \& Takata K (1999) Peptide transporter in the rat small intestine: ultrastructural localization and the effect of starvation and administration of amino acids. Histochemical Journal 31, 169-174.

Olives B, Martial S, Mattei M-G, Matassi G, Rousselet G, Ripoche P, Cartron J-P \& Bailly P (1996) Molecular characterization of a new urea transporter in the human kidney. FEBS Letters 386, $156-160$.

Olives B, Neau P, Bailly P, Hediger MA, Rousselet G, Cartron JP \& Ripoche P (1994) Cloning and functional expression of a urea transporter from human bone marrow cells. Journal of Biological Chemistry 269, 31649-31652.

Packett LV \& Groves TDD (1965) Urea recycling in the ovine. Journal of Animal Science 24, 341-346.

Potter GD, Schmidt KL \& Lester R (1983) Glucose absorption by an in vitro perfused colon of the fetal rat. American Journal of Physiology 245, G424-G430.

Puga DC, Galina HM, Perez-Gil RF, Sangines GL, Aquilera BA, Haenlein GF, Barajas CR \& Herrera HJ (2001) Effect of a controlled-release urea supplementation on feed intake, digestibility, nitrogen balance and ruminal kinetics of sheep fed low quality tropical forage. Small Ruminant Research 41, 9-18.

Ramirez M, Fernandez R \& Malnic G (1999) Permeation of $\mathrm{NH}_{3} / \mathrm{NH}_{4}^{+}$and cell $\mathrm{pH}$ in colonic crypts of the rat. Pflugers Archives - European Journal of Physiology 438, 508-515.

Richards P (1972) Nutritional potential of nitrogen recycling in man. American Journal of Clinical Nutrition 25, 615-625.

Ritzhaupt A, Breves G, Schroder B, Winckler CG \& ShiraziBeechey SP (1997) Urea transport in gastrointestinal tract of ruminants: effect of dietary nitrogen. Biochemical Society Transactions 25, S122.

Ritzhaupt A, Wood IS, Jackson AA, Moran BJ \& Shirazi-Beechey SP (1998) Isolation of a RT-PCR fragment from human colon and sheep rumen RNA with nucleotide sequence similarity to human and rat urea transporter isoforms. Biochemical Society Transactions 26, S40.
Russell K, Lobley GE, Rawlings J, Millward DJ \& Harper EJ (2000) Urea kinetics of a carnivore, Felis silvestris catus. British Journal of Nutrition 84, 597-604.

Sands JM (2003) Molecular mechanisms of urea transport. Journal of Membrane Biology 191, 149-163.

Sarraseca A, Milne E, Metcalf MJ \& Lobley GE (1998) Urea recycling in sheep: effects of intake. British Journal of Nutrition 79, 79-88.

Shen H, Smith DE \& Brosius FC (2001) Developmental expression of PEPT1 and PEPT2 in rat small intestine, colon and kidney. Pediatric Research 49, 789-795.

Singh SK, Binder HJ, Giebel JP \& Boron WF (1995) An apical permeability barrier to $\mathrm{NH}_{3} / \mathrm{NH}_{4}{ }^{+}$in isoloated, perfused colon crypts. Proceedings of the National Academy of Science USA $\mathbf{9 2}$, 11573-11577.

Smith CP, Lee W-S, Martial S, Knepper MA, You G, Sands JM \& Hediger MA (1995) Cloning and regulation of expression of the rat kidney urea transporter (rUT2). Journal of Clinical Investigation 96, 1556-1563.

Smith CP, Potter EA, Fenton RA \& Stewart GS (2004) Characterization of a human colonic cDNA encoding a structurally novel urea transporter, hUT-A6. American Journal of Physiology 287, C1087-C1093.

Smith CP \& Rousselet G (2001) Urea transporters. Journal of Membrane Biology 183, 1-14.

Steinbrecher HA, Griffiths DM \& Jackson AA (1996) Urea production in normal breast-fed infants measured with primed/ intermittent oral doses of ${ }^{15} \mathrm{~N}^{15} \mathrm{~N}$ urea. Acta Paediatrica 85, 656-662.

Stewart GS, Fenton RA, Thevenod F \& Smith CP (2004) Urea movement across mouse colonic plasma membranes is mediated by UT-A urea transporters. Gastroenterology 126, 765-773.

Tanaka N, Kubo K, Shiraki K, Koishi H \& Yoshimura H (1980) A pilot study on protein metabolism in the Papua New Guinea highlanders. Journal of Nutritional Science and Vitaminology 26, 247-259.

Tebot I, Britos A, Godeau JM \& Cirio A (2002) Microbial protein production determined by urinary allantoin and renal urea sparing in normal and low protein fed Corriedale sheep. Veterinary Research 33, 101-106.

Theurer CB, Huntington GB, Huber JT, Swingle RS \& Moore JA (2002) Net absorption and utilization of nitrogenous compounds across ruminal. Intestinal and hepatic tissues of growing beef steers fed dry-rolled or steam-flaked sorghum grain. Journal of Animal Science 80, 525-532.

Timmer RT, Klein JD, Bagnasco SM, Doran JJ, Verlander JW, Gunn RB \& Sands JM (2001) Localization of the urea transporter UT-B protein in human and rat erythrocytes and tissues. American Journal of Physiology 281, C1318-C1325.

Tombola F, Morbiato L, Del Giudice G, Rappuoli R, Zoratti M \& Papini E (2001) The Helicobacter pylori VacA toxin is a urea permease that promotes urea diffusion across epithelia. Journal of Clinical Investigation 108, 929-937.

Torrallardona D, Harris CI, Coates ME \& Fuller MF (1996a) Microbial amino acid synthesis and utilization in rats: incorporation of ${ }^{15} \mathrm{~N}$ from ${ }^{15} \mathrm{NH}_{4} \mathrm{Cl}$ into lysine in the tissues of germ-free and conventional rats. British Journal of Nutrition 76, 689-700.

Torrallardona D, Harris CI \& Fuller MF (1996b) Microbial amino acid synthesis and utilization in rats: the role of coprophagy. British Journal of Nutrition 76, 701-709.

Torrallardona D, Harris CI \& Fuller MF (2003) Pigs' gastrointestinal microflora provide them with essential amino acids. Journal of Nutrition 133, 1127-1131.

Ugawa S, Sunouchi Y, Ueda T, Takahashi E, Saishin Y \& Shimada $\mathrm{S}$ (2001) Characterization of a mouse colonic system $\mathrm{B}(0+)$ 
amino acid transporter related to amino acid absorption in colon. American Journal of Physiology 281, G365-G370.

Vaira D, Holton J, Dowsett J, Oderda G \& Barbera L (1990) Helicobacter pylori - its role in gastric disease. Digestive Diseases 8, 322-326.

Varady J, Tashenov KT, Boda K, Fejes J \& Kosta K (1979) Endogenous urea secretion into the sheep gastrointestinal tract. Physiologia Bohemoslov 28, 551-559.

Walser M \& Bondenlos LJ (1959) Urea metabolism in man Journal of Clinical Investigation 38, 1617-1626.

Waterlow JC (1999) The mysteries of nitrogen balance. Nutrition Research Reviews 12, 25-54.

Wheeler RA, Jackson AA \& Griffiths DM (1991) Urea production and recycling in neonates. Journal of Pediatric Surgery 26, $575-577$.

Wiklund L, George M, Nord CE, Ronquist G \& Saldeen T (1998) Sudden infant death syndrome and nitrogen metabolism: further development of a hypothesis. European Journal of Clinical Investigation 28, 958-968.

Wolfe RR (1981) Measurement of urea kinetics in vivo by means of a constant tracer infusion of di-15N-urea. American Journal of Physiology 240, E428-E434.

Wolpert E, Phillips SF \& Summerskill WH (1971) Transport of urea and ammonia production in the human colon. Lancet ii, $1387-1390$
Wrong OM (1967) The metabolism of urea and ammonium in the healthy and uraemic colon. Medical Journal of Australia 12, $281-283$.

Wrong OM (1971) Intestinal handling of urea and ammonium. Proceedings of the Royal Society of Medicine 64, 1025-1026.

Wrong OM (1978) Nitrogen metabolism in the gut. American Journal of Clinical Nutrition 31, 1587-1593.

Wu ZC, Chijang CC, Lau BH, Hwang B, Sugawara M \& Idota T (2000) Crude protein content and amino acid composition in Taiwanese human milk. Journal of Science and Vitaminology 46 , 246-251.

You G, Smith CP, Kanai Y, Lee W, Stelzner M \& Hediger M (1993) Cloning and characterization of the vasopressin-regulated urea transporter. Nature 365, 844-847.

Younes H, Demigne C, Behr SR, Garleb KA \& Remesy C (1996) A blend of dietary fibers increases urea disposal in the large intestine and lowers urinary nitrogen excretion in rats fed a low protein diet. Nutritional Biochemistry 7, 474-480.

Ziegler TR, Fernandez-Estivariz C, Gu LH, Bazargan N, Umeakunne K, Wallace TM, Diaz EE, Rosado KE, Pascal RR, Galloway JR, Wilcox JN \& Leader LM (2002) Distribution of the $\mathrm{H}^{+}$/peptide transporter PepT1 in human intestine: upregulated expression in the colonic mucosa of patients with shortbowel syndrome. American Journal of Clinical Nutrition $\mathbf{7 5}$, 922-930. 